\title{
Correspondence
}

\section{Measurement of oxygen consumption in infants}

Sir,

The paper by Evans et al. (Archives, 1978, 53, 330) describing a simple method for measuring oxygen consumption contains inaccuracies I should like to correct.

The assertion that methods using a lower flow rate 'almost certainly result in $\mathrm{CO}_{2}$ retention' is wrong. The method described by me (Smales, 1978) uses a flow rate of $1 \mathrm{l} / \mathrm{min}$ and by sampling continuously from the nares in a term infant we were unable to demonstrate any alteration in the $\mathrm{CO}_{2}$ profile using the Edward's medishield medical mass spectrometer. At $500 \mathrm{ml} / \mathrm{min}$, however, baseline shift was observed.

In addition when oxygen consumption was measured at various flow rates between 1 and $31 / \mathrm{min}$ no significant differences were observed. I would suggest that the reason for this is that when a constant bias flow is applied to the proximal channel, flow rates exceeding this may occur during expiration through the distal part of tubing. In the method described by Evans et al. the flow rate of mixed expiratory gases through the distal tubing is constant and must therefore be higher to avoid $\mathrm{CO}_{2}$ retention.

Although they omitted my data from their list of comparative values of $\mathrm{VO}_{2}$ in neonates, Evans et al. will find that there is also close agreement with previous workers.

O. R. C. SMales

Nottingham City Hospital, Hucknall Road, Nottingham NG5 IPB

\section{Reference}

Smales, O. R. C. (1978). Simple method for measuring oxygen consumption in babies. Archives of Disease in Childhood, $53,53-57$.
Dr Evans and co-workers comment:

Dr Smales differs with us over our reason for using higher gas flows than he feels are necessary. It is our justification for this that he labels inaccurate. We firmly adhere to our belief that gas flows in excess of $11 / \mathrm{min}$ are mandatory to prevent rebreathing in the mature newborn who has a peak inspiratory flow rate of over $21 / \mathrm{min}$, therefore gas flows less than this, for instance $1 \mathrm{l} / \mathrm{min}$, will inevitably cause some rebreathing. This was predicted (Onchi et al., 1957) and demonstrated experimentally (Willis et al., 1975). Our experience leads us to the conclusion that to prevent $\mathrm{CO}_{2}$ retention the gas flow has to be at least twice the minute volume. Figs 1 and 2 show $\mathrm{CO}_{2}$ analysis in gas expired from the nostrils of a $2.5 \mathrm{~kg}$ newborn infant using a mass spectrometer (Centronic MGA 200). When the flow through the mask is $11 / \mathrm{min}$, the inspired $\mathrm{CO}_{2}$ concentration rises to between 1 and $2 \%$ and the ventilatory rate increases from 38 to $47 / \mathrm{min}$ (Fig. 1). When the flow is raised to $3.31 / \mathrm{min}$ (Fig. 2), there is still some rebreathing of the first breaths but this does not occur later. It is essential that $\mathrm{CO}_{2}$ is not retained during the measurement of oxygen consumption as the increased carbon dioxide level causes a rise in ventilatory rate, increased work, and thereby a rise in oxygen consumption.

The relative patterns of gas flows in the limbs of the circuit are not relevant to the problem of rebreathing (Onchi et al., 1957). The essential factor is the net gas flows through the mask. It is this which determines whether or not rebreathing will occur.

We are not able to account for Dr Smales's inability to demonstrate $\mathrm{CO}_{2}$ retention on low gas flows. This is contrary to other reports (Onchi et al., 1957; Willis et al., 1975). We did not compare his results with ours because the populations studied were different. Dr Smales's

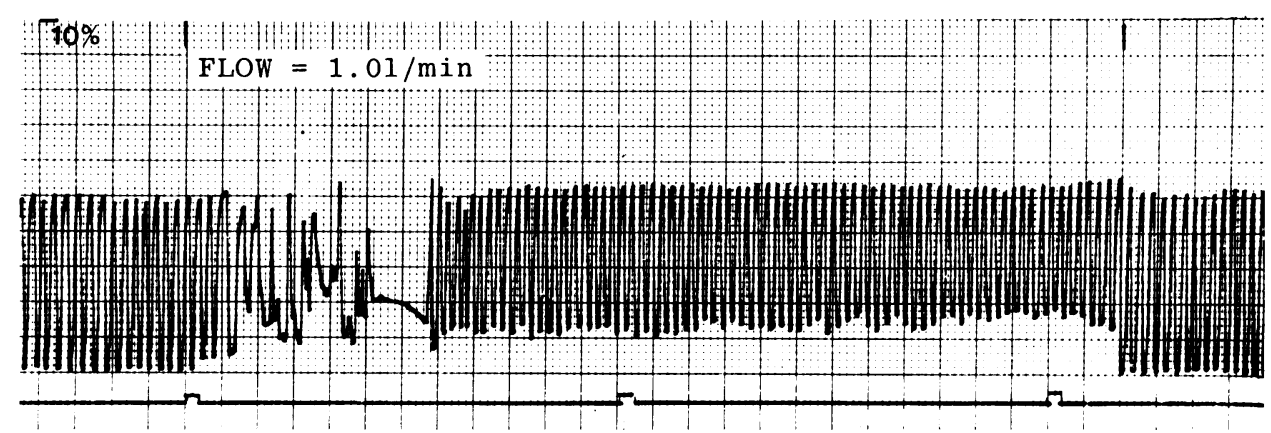

Fig. $1 \mathrm{CO}_{2}$ concentration in expired gases of a $2.5 \mathrm{~kg}$ newborn infant; flow rate $1.0 \mathrm{l} / \mathrm{min}$. 


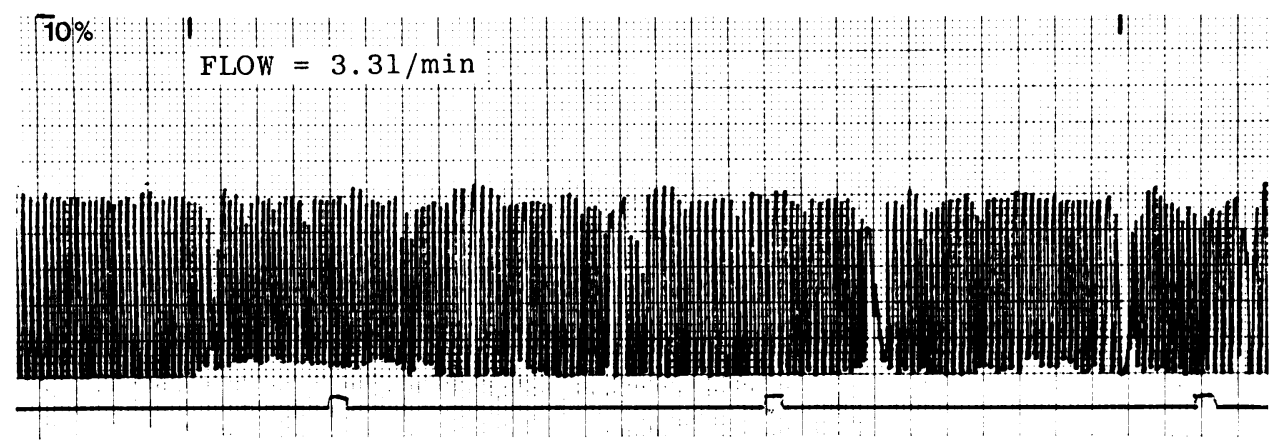

Fig. $2 \mathrm{CO}_{2}$ concentration in expired gases of a $2.5 \mathrm{~kg}$ newborn infant; flow rate $3.3 \mathrm{l} / \mathrm{min}$.

group comprised mixed referrals to his unit; our patients were term mature infants.

J. M. Evans, O. P. Gray, Barbara Holland, and C. A. J. WARDrop Departments of Anaesthetics, Child Health, and Haematology, Welsh National School of Medicine, University Hospital of Wales, Heath Park, Cardiff CF4 4XN

\section{References}

Onchi, Y., Hayashi, T., and Ueyama, H. (1957). Studies on the Ayre T-piece technique. Far East Journal of Anaesthesia, 1, 30-35.

Willis, B. A., Pender, J. W., and Mapleson, W. W. (1975). Rebreathing in a T-piece: volunteer and theoretical studies of the Jackson-Rees modification of Ayre's T-piece during spontaneous respiration. British Journal of Anaesthesia 47, 1239-1246.

\section{Nonhormonal case of adrenal cortical carcinoma}

Sir,

Further to the two articles by Marsden et al. and Visconti et al. regarding adrenal carcinoma in infants (Archives, 1978, 53, 341 and 342) may we add the following account of a child with this extremely rare condition.

A 17-month-old white girl was admitted with a 20day history of malaise, pallor, and high fever $\left(39^{\circ} \mathrm{C}\right)$. She was born after a normal pregnancy and delivery, to a 25-year-old gravida 2, para 2 woman. Physical examination on admission showed anaemia; both liver and spleen were $2 \mathrm{~cm}$ below the costal margins. No signs of precocious puberty were present, and the clitoris was not enlarged. Blood pressure was normal.

Hb was $7.8 \mathrm{~g} / \mathrm{dl}$, red blood cells being hypochromic; ESR $90 \mathrm{~mm}$ in the 1st hour; serum iron $28 \mu \mathrm{g} / 100 \mathrm{ml}$ (5 $\mu \mathrm{mol} / \mathrm{l})$, TIBC $275 \mu \mathrm{g} / 100 \mathrm{ml}(49 \mu \mathrm{mol} / \mathrm{l})$. Urine analysis normal. Blood and urine culture negative. Urinary VMA $6 \cdot 2 \mathrm{mg} / 24 \mathrm{~h}$ (normal 0.6-7). Bone marrow aspirate showed good cellularity with active myelopoiesis. Blood chemistry-including total protein, bilirubin, sugar, urea, cholesterol, electrolytes, and uric acid was normal. Chest $x$-ray normal.

Four days after admission the patient developed redness and oedema of both eyelids, and on the left frontal region. At that time we also found a palpable lobular mass $6 \mathrm{~cm}$ below the right costal margin. Skull $x$-ray revealed a well defined osteoporotic lesion corresponding with the mass in the left frontal region. A second $x$-ray of the skull 3 days later showed at the same site a picture of osteolysis, and an osteolytic lesion of the left humerus was also present. Intravenous pyelogram showed the right kidney to be displaced downwards. Urinary 17-hydroxysteroids were $0.9 \mathrm{mg} / 24 \mathrm{~h}(3.1 \mu \mathrm{mol} / 24 \mathrm{~h}$ ) (normal for age 1-3.5 $\mathrm{mg} / 24 \mathrm{~h} ; 3 \cdot 5-12 \cdot 1 \mu \mathrm{mol} / 24 \mathrm{~h}$ ), and 17-ketosteroids were zero. Plasma cortisol was $5 \mu \mathrm{g} / 100 \mathrm{ml}(138 \mathrm{nmol} / \mathrm{l})$ in the morning and $4.5 \mu \mathrm{g} / 100 \mathrm{ml}(124 \mathrm{nmol} / \mathrm{l})$ in the evening.

Complete excision of the tumour of the right adrenal was achieved surgically. It was covered by a thin capsule, and measured $12 \times 8 \mathrm{~cm}$. The cut surface was reddishbrown and showed areas of recent and old haemorrhage and evidence of necrosis. Histologically, there were cells with pleomorphic nucleus and a variable amount of cytoplasm, which confirmed adrenal cortical carcinoma. Postoperative chemotherapy with adriamycin was unsuccessful and the patient died 2 months later. Urinary 17-hydroxysteroids, 17-ketosteroids, and plasma cortisol, measured 10 days after surgery, were within normal levels.

\section{A. Constantopoulos, J. Karpouzas, A. XYPolita, and N. MATSANIOTIS 1st Paediatric Clinic of Athens University, Aghia Sophia Children's Hospital, Athens (608), Greece}

\section{Effect of storage and heat on antimicrobial proteins in human milk}

Sir,

The paper by Evans et al. (Archives, 1978, 53, 239) confirms other work on the temperature sensitivity of human milk proteins (Ford et al., 1977; Gibbs et al., 1977). Some of their conclusions deserve comment. 